\title{
Global Hypothesis of Civilization and Philosophy, Metaphysics of Sciences
}

\section{Shahidipak $\mathbf{M}^{*}$}

Islamic Azad University Central Tehran Branchm, Iran

*Corresponding author: Mohammadreza Shahidipak, Islamic Azad University Central Tehran Branch, Iran, Email: reza2018mreza@gmail.com

Research Article

Volume 2 Issue 3

Received Date: July 19, 2019

Published Date: August 05, 2019

DOI: $10.23880 /$ phij-16000122

\section{Abstract}

The close relationship between philosophy with civilization and sciences is one of the world's theorien.in the eastern of the world Farabi(950.AD), Razi(925A.D), Nasiruddin Tusi(1274AD), Ibn Arabi(6ó1240AD), Ibn Khaldun (1406AD), the founders of Islamic civilization and among the western thinkers there are Freud, Yang, Kant, Hegel(1831AD), Gennon, Gibbon(1897AD), Gustavolubon, Sarton(1995AD), Toynbee(1975AD) and Durant, have presented hypotheses about the relation between civilization and philosophical fields ,among them, Farabi explained the theoretical nature of civilization and its relation with philosophy Farabi's theory reversed by the views of Plato and Aristotle. Ibn Arabi mentioned the metaphysical route of civilization but Ibn Khaldun's report is about areas of the world where civilization is flourishing, while at this place philosophy is welcomed, he used the Quranic word and built the term civilization and equated it with the science of history. He compared the state of philosophy in Europe and the Muslim world, he wrote the flow of philosophy in Europe awake but it is being silent in the Muslim world. This view is mentioned in framework of Ibn khaldun report of the simultaneous fall of Andalusia and degeneration of Islamic civilization with coinciding the philosophical and theological and metaphysical developments. Including in the case of Iran he wrote philosophical thoughts is alive by scientists such as Nasir al-Din al-Tusi. Sarton clarified the relation between civilization and philosophy in the history of world science. Toynbee examines the essence and emergence and fall, development, global transitions of civilizations, but in a political approach to contemporary European-American civilization, it has adopted specific positions on contemporary civilizations. He made this special comment on the issue of the relationship between power and civilization and its symbol the atomic energy by Preserve civilization by NPT. Research is a compilation of the author's articles since 2000 which is part of the book" The Concept of Science in Islamic civilization "the question is dose philosophy make progress the article answers this question with a historical reason that is direct relationship between philosophy and science that they inform each other.

Keywords: Philosophy; civilization; Toynbee; NPT 


\section{Introduction}

\section{The Concept and Exemplified of Civilization, Subject of Studies between the Humanities:}

Civilization is compound conceptual which today is among the interdisciplinary studies in the field of humanities in the Christian world .and it was decorated and Infected and contaminated to the good and evil of this category of studies [1]. The concept of civilization in the same time is a subject of study at philosophical research and sociology, sociology of religions, psychology of Freud, political sciences of theology and theology, anthropology, geography and ethnology [2]. The present paper, which attribution and describes the relationship between civilization and philosophy, there is no purely philosophical definition of the concept of civilization. it has been defined by most interventions and derivatives of civilization in political philosophy such as city and citizen and citizenship [3].

\section{The Relationship of Civilization and Philosophy in the West's Theories of the Humanities}

Freud, Auguste Kent, Gustavo, Toynbee, Hegel, in the collections of Western humanities, are scientists and indicators for determining the relation between philosophy and civilization. Gustavlobon writes in his book The Development of Nations, which is influenced by Ibn Khaldun, the elements of the civilization of nations (arts, sciences, industries, philosophy, ethics, religions, and administrations) derive from the spirit of all nations and their special effects are their mental temperament [4]. Which will not be transmitted to the other nation in the same way and the human history is a thick volumes and indeed it is a frequent of one page, and each nation gradually reaches the height of excellence and with the loss of morality and human virtues and values, will be lost in a little while his image of civilization is like the Freudian image of civilization Which has considered civilization and a sense of dissatisfaction as a coincidence [5]. According to Gustavoulen opinion, civilization has created two deviations in contemporary human thought, and writes: "The civilization is a mother of terrible jumble of communism and anarchism in the human mind.today's civilized human being is in the one of the most difficult historical periods due to the effects of the thought of communism and anarchism in his view philosophy don't not able to explain the process of civilization, and only the power of faith and belief is capable for understanding civilization.in his dialectical expression there is between civilization and changes just in the secondary ethics of nations as in Freud's dialectical imagination, civilization is between supplying instincts and social prerequisites. The common product of the view of Freud and Gustav Lobon is that both of them emphasize that dissatisfaction of mankind is produced of civilization. In contemporary period August Kenneth just determined the ratio between philosophy of natural science and evolution of civilization in human history [6]. In modern thought, the close relation and link between civilization and philosophy has been explained and criticized in Hegel's philosophy because philosophy, according to Hegel, is the dialectical explanation of the history of civilization.in his Dialectic, which is based on metaphysics, the civilization of nations has been transformed in two forms: Civilizations are static forms and evolving .In the general dialectic of Hegel, civilization is the result of contradiction and his object and aim is liberation [7].

\section{Hegel and the Relation between Philosophy and Civilization and Popper's Critique of it, Hegel's Naughtiness}

Popper, a contemporary English political philosopher, is the answer to the question of what is philosophy more than any other person. He criticized the and destroyed a building of philosophy, which for centuries had a physical position in the field of philosophical thought in the world and is one of the main elements of philosophical thought, especially continental and analytic philosophy, and is a very tall skyscraper. In the city of philosophy. it is not possible to understand and see all its height at a glance, such as seeing a sky scraper with a look and even a few superficial look [8] and this very tall building is a Hegelian philosophy system that in many countries and universities there is a special seat for the teaching of Hegel's philosophy [9]. Hegel seems to have built up a complex philosophical system among Western thinkers to explain the the movement and evolution and course of civilization. Nevertheless, the contemporary historian of philosophy, the political philosopher of the school of analytic philosophy of England, Carl Popper, has often described Hegel's philosophical system as a Hegel's Naughtiness [10] but indeed, hegel has brought the most complex and deepest philosophical system to explain civilization in the world.is really the Hegelian philosophical system a kind of naughtiness? of course, Popper's critique of Hegel has many benefits and the close benefits is the practical answer to the question of what is philosophy. Popper's critique of Hegel is, in fact, an indication of the identity of philosophy because Philosophy is a philosophical critique.

\section{Toynbee, Preserve Civilization by NPT}

Toynbee, a historian and the essence of civilization, is the containment of contemporary civilization with the 


\section{Philosophy International Journal}

ruling power with the International Organization for the Control of Nuclear Energy. nuclear energy is the tip of the contemporary American-European civilization that Toynbee has spoken about it he is a contemporary historian of civilization who expressed civilization in a work titled "story of Civilization" in several volumes.he has written numerous works on civilization and he is leader of civilizationgraphy in contemporary times [11] he has divided the civilization based on new category by tree mapping into 21,26, 24 civilization types,some titles of his book are rise and fall of civilizations and Spatial and temporal relationships between civilizations and elite minority and their role in civilization. The interesting thing about Toynbee is that he proposes a nuclear power control in the world his name is at top of list that who believes in controlling energy in any civilizationand and modern energy of new civilization must be controlled and distributed in a particular way and discipline in the global civilization. this historian of civilization has stated its theoretical foundations for world control of energy. This Toynbee's intellectual action on nuclear energy is invaluable as historian. He showed the close relation between civilization and philosophy special political philosophy. The theory of control over the distribution of nuclear energy in the world is based on the philosophy of power.

\section{George Sarton and the Academic Explanation of the Relationship between Civilization and Philosophy}

George Sarton is the only historian of civilization who first identified the relationship between civilization and philosophy in expressing the international image of civilization it has identified its philosophical fields in every universe and in different places of the world. The emergence of Islam in the Middle Ages is the main philosophical and cultural background of the advent of civilization which is considered by historians of the civilization as a Durant and Toynbee and Hunke in her Ph.D. Thesis $[12,13]$. They have focused on the physical role of the Prophet of Islam and the philosophical thoughts after him in building foundations of civilization. he described the Philosophical Context of the Thirteenth Century as a fundamental step in the history of world science, especially in the Maghreb, Andalusia and Europe, and at that time, science was transferred to Europe and the fields of Renaissance were provided [14] he introduced Philosophical backgrounds of the Thirteenth Century. They were English philosopher, including Scott and Robert Grossest and German philosopher and Italian philosophers at the court of Frederick II and the French philosopher as Guillaume and Islamic philosophers as Ibn -Arabi, Ibn, Sabayn [15].

\section{Ibn Khaldun as a European discovery}

Many of Europeans scholars have identified Ibn Khaldun as a European discovery and considered him part of Western civilization but there are still many Orientalists who introduce him with a religious personality and part of the evolution of Islam civilization. The European Orientalist, as a Lucyian Boa and Hughes Marine [16]. Interpreted Ibn Khaldun as a great painter of Islamic civilization.Ibn Khaldun has brought historical evidence of many of the two civilizations in the East and West of the Islamic world to prove this hypothesis that variable civilization is related to philosophy [17-19].

\section{Conclusion}

There is a direct relationship between civilization and philosophy, and each civilization is formed on the basis of its particular theoretical background and the philosophy is a grammar of the emergence of civilizations and rexamine and rethinking the views of philosophers and historians of civilization proved the Global hypothesis of civilization and philosophy, and there is in history of sciences the metaphysical grammars rules and govern the circulation and transfer of science among nations and they are the same Metaphysics of sciences.

\section{References}

1. Glorieux J (2009) Lexique des scoiences humaines. Lyon, pp: 8-9.

2. Gellner (1993) Encyclopedia of sociology. Transl by Chavoshyan, pp: 282-283.

3. (2005) Rutledge encyclopedia of philosophy. pp: 123.

4. Gustavlobon (1985) The Development of Nations. Transl by Dashti. pp: 12x,70,88,136,174.

5. Freud S (2002) Civilization and Its Discontents. Transl by Mobashery, pp: 45,78,90.

6. Aron R (1987) Main current in sociological thought. Transl by Parham, $1^{\text {st }}$ (Vol), pp: 81,92,103,136.

7. Hegel F (2000) Wisdom in history. Transl by Anayat, pp: 165,182,206,266.

8. Beiser F (2017) Hegel. Transl by Hosaini, pp: $67,82.157,215,261,287,317,413,416$. 


\section{Philosophy International Journal}

9. Hyppolite J (1983) Introduction a la philosophie de l h'istoire de Hegel. Transl by Parham, pp: 5,41,79.

10. Popper $C$ (2001) The open socities and its enemies 1945. Translated by Fuladvand, pp: 158,725.

11. Toynbb (1967) Story of Civilization. $1^{\text {st }}$ (Vol), pp: $345,369,456$.

12. Rosental F (2005) The classical heritage of Islam. Transl by Palasid, pp: 32,47,79,142,197,271,295.

13. Hunke S (1963) "Allah's sun over the Occident". Transl by Rahbani, Rezvani. pp: 34,45,78,90,456.

14. Shahdipak M (2012) Comparative Investigating in the Paradigm of Transference of Science. The Case Andalusia at the End of Medieval, Jeju Island, South Korea, pp: 167,170.
15. Sarton G (1999) The introduction to the history of sciences, 1975. Transl by Afshar, pp: $900,1250,2300,3607$.

16. Hughes M (2000) Fifty Key thinkers on history. Transl bBadei, pp: 266,269,270,274.

17. Ibnkhaldun (1999) Introduction. pp: $100,560,879,980,996$.

18. Cahhen C (2010) L' Islam 1995. Transl by Ghbaysi, pp: $25,31,289,407$.

19. Durant W (193) Story of civilization.1993, Transl by Farhangishop, $1^{\text {st }}$ (Vol.), pp: 100,134,166,v4,p,1. 